\title{
Fumigant toxicity of eugenol and its negative effects on biological development of Callosobruchus maculatus $\mathrm{L}$
}

\author{
Toxicidad fumigante del eugenol y sus efectos negativos en el desarrollo \\ biológico de Callosobruchus maculatus L
}

\section{Maria José González Armijos. ${ }^{1}$; Luis Oswaldo Viteri Jumbo. ${ }^{2}$; Lêda Rita D’Antonino Faroni ${ }^{3}$; Eugenio Eduardo Oliveira ${ }^{4}$; Adolfo Fernando Flores ${ }^{5}$; Fernanda Fernandes Heleno. ${ }^{6}$; Khalid Haddi. ${ }^{7}$}

1 Ing. Agropecuaria, Universidad Nacional de Loja, Loja, Equador, majito130692@gmail.com.

2 Dr. Departamento de Entomologia, Universidade Federal de Viçosa, Viçosa, MG, Brazil, luis.jumbo@ufv.br.

Dr. Departamento de Engenharia Agrícola, Universidade Federal de Viçosa, Viçosa, MG, Brazil, lfaroni@ufv.br.

4 Dr. Departamento de Entomologia, Universidade Federal de Viçosa, Viçosa, MG, Brazil, eugenio@ufv.br.

5 M.Sc. Universidad Nacional de Loja, Loja, Equador, adolfo.flores@unl.edu.ec.

6 Ph.D. Director, Serviço Autônomo de Água e Esgoto - SAAE, Senador Firmino, Minas Gerais, Brasil. fernandafhg@gmail. com.

7 Dr. Departamento de Entomologia, Universidade Federal De Lavras, Lavras, Minas Gerais, Brazil, khalid.haddi@ufv.br.

Cite: González Armijos, M.J., Viteri Jumbo, L.O., Faroni, L.R., Oliveira, E.E., Flores, A.F., Heleno, F.F. \& Haddi, K. (2019). Fumigant toxicity of eugenol and its negative effects on biological developmente of Callosobruchus maculatus L. Revista de Ciencias Agrícolas. 36(1):5-15. doi:http://dx.doi.org/10.22267/ rcia.193601.94

Received: July $202018 . \quad$ Accepted: May 162019.

\begin{abstract}
The protection of stored products from insect damages, when accomplished, is mostly relying on the application of synthetic insecticides with serious health and environmental issues in addition to risks of selection of resistant insect populations associated with such practice. The use of plants derived compounds has been presented as sound strategy for sustainable insect pest management. Eugenol is
\end{abstract}


an aromatic component of natural occurrence in essential oils of numerous plants and known for its repellent and insecticidal bioactivities against different insect species. Here, we investigated the fumigant application of eugenol to control the cowpea weevil Callosobruchus maculatus (Coleoptera: Chrysomelidae: Bruchinae) by assessing toxicity, effects on biological development (including emergence inhibition) and repellency to these weevil. Besides a good fumigant insecticidal activity, eugenol exposure resulted in a dose-dependent decrease of the growth rate of $C$. maculatus associated with a steady reduction in bean mass losses. Additionally, significant inhibition of the offspring emergence was achieved after the exposure of parental adults to lethal and sublethal doses of eugenol. Furthermore, adult weevils were repelled away from beans exposed to high dose $\left(\mathrm{LD}_{99}\right)$ of eugenol in contrast with their attraction to the beans treated with lower dose $\left(\mathrm{LD}_{50}\right)$. Our findings suggest that eugenol has potential as control tool to be used in sustainable management startegies of C. maculatus.

Key words: bean; bioactivity; cowpea weevil; natural compound.

\section{RESUMEN}

La protección de productos almacenados contra daños causados por insectos, cuando se realiza, se basa principalmente en la aplicación de insecticidas sintéticos con graves problemas de salud y medioambientales, además de riesgos de selección de poblaciones de insectos resistentes asociadas con dicha práctica. El uso de compuestos derivados de plantas ha sido presentado como una estrategia sólida para el manejo sustentable de insectos plagas. Eugenol es un componente aromático de ocurrencia natural en aceites esenciales de varias plantas, conocido por su bioactividad repelente e insecticida contra diferentes especies de insectos. En este estudio se investigó la aplicación vía fumigante del eugenol en el control del gorgojó de fríjol caupi, Callosobruchus maculatus (Coleoptera: Chrysomelidae: Bruchinae), evaluando la toxicidad, efectos en el desarrollo biológico (incluyendo inhibición de la emergencia) y repelencia a estos gogojos.. Además de una buena actividad insecticida vía fumigante, la exposición al eugenol resultó en una disminución de la tasa de crecimiento de C. maculatus dependiente de la dosis; y una reducción constante en la pérdida de masa del fríjol. Adicionalmente, una inhibición significativa de la emergencia de la descendencia se logro cuando los adultos fueron expuestos a concentraciones letales y subletales de dosis de eugenol. Además, los gorgojos adultos fueron repelidos cuando los granos de fríjol fueron tratados con dosis altas $\left(\mathrm{LD}_{99}\right)$ de eugenol y atraídos cuando se aplicaron dos dosis más bajas $\left(\mathrm{LD}_{50}\right)$. Nuestros resultados sugieren que eugenol tiene potencial como una herramienta de control para ser usado en estrategias de manejo sustentable de C. maculatus.

Palabras llaves: fríjol, bioactividad, gorgojo do fríjol, compuesto natural.

\section{INTRODUCTION}

Cowpea, Vigna unguiculata L. Walp, is a Leguminosae

species widely cultivated in tropical and subtropical countries. With protein content of about $23 \%-25 \%$, cowpea is a good protein source suitable in the diet of many people in third world countries (Kaliramesh et al., 2013; Mkenda and Ndakidemi, 2014; Purohit et al., 2013). However, cowpea production especially at small level farmers can suffer high losses of weight, nutritional value and viability of stored grains due to various insect pests in field as well as during storage (Mkenda and Ndakidemi, 2014). 
The cowpea seed beetle Callosobruchus maculatus (Coleoptera: Chrysomelidae: Bruchinae), a cosmopolitan pest of legume seeds both in stores and in the field, is among the most serious pests in stored product in tropical countries (Haddi et al., 2018; Lopes et al., 2018; Massango et al., 2017) being able to cause losses up to $100 \%$ of stored cowpea beans within few months (Kang et al., 2013; Melo et al., 2015). The control of this insect pest, when accomplished, is mainly achieved by the application of synthetic molecules such as phosphine and pyrethroid insecticides (Freitas et al., 2016), with serious risks of selecting resistant populations as well as increased hazard to human health and environment (Gbaye et al., 2016; IturraldeGarcía et al., 2016).

Plant products such as essential oils and their major constituents are known to possess insecticidal or repellent activities and have long been portrayed as safe to the environment or to human health leading to research efforts being currently focused on the use of these plant products in pest control (Haddi et al., 2017; Isman and Grieneisen, 2014; Pavela and Benelli, 2016).

Eugenol is a naturally occurring component of essential oils extracted from numerous plants of the Lauraceae family including cloves (Szygium aromaticum, Eugenia aromatica, or Eugenia caryophyllus), cinnamon (Cinnamomum spp.), basil (Ocimum spp.), allspice (Pimenta dioica), bay laurel (Laurus nobilis) and turmeric (Curcuma longa). Essential oils of some species of this family have concentrations of this compound higher than 90\% (El-Maati et al., 2016; Viteri Jumbo et al., 2014). Although essential oils with this compound are toxic to various arthropods (i.e. Sitophilus granarius, Acanthoscelides obtectus, Coptotermes formosanus, Periplaneta Americana, Camponotus pennsylvanicus) with promising results under laboratory conditions and are being considered as alternative strategies for insect pest management (Polatoğlu and Karakoç, 2016; Viteri Jumbo et al., 2014; Chang S. and Cheng S. 2002, Enan E. 2001), the effects of isolated eugenol on stored grains pests especially when applied as fumigant has been rarely studied.

Here, we evaluated the fumigant effect of eugenol by assessing the insecticidal (lethal toxicity, effects on biological develpoment and emergence inhibition) and repplency activities of eugenol on the cowpea weevil C. maculatus in fumigant applications.

\section{MATERIAL AND METHODS}

\section{Callosobruchus maculatus populations.} Insects of $C$. maculatus used in all experiments were originally field-collected from small farms in the Viçosa region (Minas Gerais State, Brazil). Populations of these insects were maintained under laboratory conditions $\left(27 \pm 2{ }^{\circ} \mathrm{C}, 75 \pm 5 \%\right.$ $\mathrm{RH}, 12$ h scotophase) on cowpea beans. To avoid possible infestations from the field and to reduce the potential effects of residual insecticides, the cowpea beans were stored at $-18^{\circ} \mathrm{C}$ for 15 days. The cowpea beans moisture content was $11 \%$, before being offered ad libitum to C. maculatus.

Fumigant toxicity bioassay. Comercial formulation of liquid eugenol (99\% pure) was acquired from Sigma-aldich (Sao paulo, SP State, Brazil).

The bioassay of fumigant toxicity of the eugenol was performed following previously described methods (Massango et al., 2017). Briefly, in $0.8 \mathrm{~L}$ glass jars, $50 \mathrm{~g}$ of beans and twenty unsexed 1-2 days old $C$. maculatus adults were placed. The eugenol was applied to $5 \mathrm{~cm}^{2}$ of filter paper (Wattman $\mathrm{N}^{\circ} 1$ ) clips, using a $100 \mu \mathrm{L}$ microsyringe (Hamilton, Reno, NV, USA), that were attached to a cotton wire and hung to the caps' inner surface to serve as oil diffuser. The jars were hermetically sealed with metal screw cap 
reinforced with silicone adhesive in a completely randomized design. The doses used were 0.0 (control), 12.5, 18.75, 25.0, 37.50, 50,0 $\mu \mathrm{L}$ of eugenol $\mathrm{L}^{-1}$ air and five replications were used per each dose. The insect mortality was recorded after 24 hours exposure period. Insects were considered dead if they do not respond to a stimulus with a fine paintbrush.

Instantaneous rate of increase $\left(r_{i}\right)$ and grain losses bioassays. The instantaneous rate of increase $\left(r_{i}\right)$ test was carried out in $0.8 \mathrm{~L}$ glass jar where 20 unsexed adults of $C$. maculatus of 1-2 day old were allowed to colonize $50 \mathrm{~g}$ of exposed beans with eugenol based on the dose-mortality results previously obtained (see results section). Five doses were used: 13.46, 20.64, $29.80,45.66$, and $134.13 \mu \mathrm{L}$ of eugenol $\mathrm{L}^{-1}$ air that corresponded to $\mathrm{LD}_{20}, \mathrm{LD}_{40}, \mathrm{~L}_{60}, \mathrm{LD}_{80}$ e $\mathrm{LD}_{99}$, respectively; applied in the same conditions of bioassays toxicity. Five replicates were used for each concentration. All the glass jars were maintained at $27 \pm 1^{\circ} \mathrm{C}, 75 \pm 5 \%$ relative humidity and $12 \mathrm{~h}$ of scotophase. The control treatment did not receive any eugenol application. The number of insects emerged (F1) was counted after 45 days and the instantaneous rate of increase in each population was calculated for each concentration as follows: $r_{i}=\left(N_{\mathrm{f}} / N_{\mathrm{i}}\right) / \Delta t$; Where: $N_{\mathrm{f}}$ is the final number of observed live adults; $N_{\mathrm{i}}$ is the initial number of $C$. maculatus and $\Delta t$ is the duration of the experiment (Walthall and Stark, 1997).

The grains masses provided for the insect colonization were weighed using an analytical scale (GEHAKA bk 800, Shimadzu, Tokyo, Japan) at the start and the end (after 45 days) of the bioassays to calculate the percentage of grain losses.

Emergence bioassay. The bioassays for the daily emergence were conducted using the same experimental procedures described for the instantaneous rate of increase $\left(r_{i}\right)$. Only four doses with four replicates were used: 0, 13.46, 29.80 and $134.13 \mu \mathrm{L}$ of eugenol $\mathrm{L}^{-1}$ air corresponding to control, $\mathrm{LD}_{20}, \mathrm{LD}_{60}$, and $\mathrm{LD}_{99}$. The progeny of the adult $C$. maculatus obtained from the beans were assessed every two days starting from the $22^{\text {th }}$ day after the treatments.

Repellence bioassay. The repellency experiment was conducted in an apparatus consisting of five circular plastic containers $(12 \mathrm{~cm}$ diameter, $8 \mathrm{~cm}$ height), with a central container (E) connected to the other four containers (A, B, C and D) by plastic cylinders (12 cm long, $1 \mathrm{~cm}$ in diameter), as previously described (Viteri Jumbo et al., 2014). Containers A and B were arranged diagonally and filled with $50 \mathrm{~g}$ of cowpea beans exposed to eugenol (two doses were used [in $\mu \mathrm{L} / \mathrm{L}^{-1}$ ]: $\mathrm{LD}_{50}$ $=28.80$ or $\mathrm{LD}_{99}=134.13$ ). Containers $\mathrm{C}$ and $\mathrm{D}$ were filled with $50 \mathrm{~g}$ of cowpea beans untreated (control). In the center container, 50 unsexed adults were released, and after $24 \mathrm{~h}$, the total number of insects per container was recorded.

Statistical analyses. Concentration-mortality curves were estimated according to probit analyses using the PROC PROBIT SAS software, version 9.2, of the SAS System for Windows (SAS Institute, Cary, NY). Regression analyses were performed to detect trends in the $r_{i}$ and grain mass losses, cumulative and daily emergence that resulted in each treatment through time. Regression analysis was performed using the curve-fitting procedure of SigmaPlot 12.0 (Systat Software, San Jose CA, USA). The regression model was chosen based on parsimony, lower standard errors, and steep increases in $\mathrm{R}^{2}$ with model complexity. Paired t test was used for the analysis of repellence.

\section{RESULTS AND DISCUSION}

Fumigant toxicity of eugenol to $C$. maculatus. The dose-mortality data were satisfactorily described by the probit model [goodness-offit tests exhibiting low $\chi^{2}$-values $(<10)$ and high $P$-values ( $>0.05)]$. The LDvalues are given in Table 1. 
Table 1. Fumigant toxicity of eugenol to C. maculatus.

\begin{tabular}{|c|c|c|c|c|c|c|c|c|c|}
\hline $\begin{array}{l}\text { Insect } \\
\text { number }\end{array}$ & $\begin{array}{l}\text { Slope } \\
\left( \pm \mathrm{SD}^{1}\right)\end{array}$ & $\begin{array}{c}\mathrm{LD}_{20} \\
\text { (FI 95\%) }\end{array}$ & $\begin{array}{c}\mathrm{LD}_{40} \\
\text { (FI 95\%) }\end{array}$ & $\begin{array}{c}\mathrm{LD}_{50} \\
\text { (FI 95\%) }\end{array}$ & $\begin{array}{c}\mathrm{LD}_{60} \\
\text { (FI 95\%) }\end{array}$ & $\begin{array}{c}\mathrm{LD}_{80} \\
\text { (FI 95\%) }\end{array}$ & $\begin{array}{c}\mathrm{LD}_{99} \\
\text { (FI 95\%) }\end{array}$ & $X^{2}$ & $P$ \\
\hline 600 & $\begin{array}{c}3.17 \\
\pm 0.25\end{array}$ & $\begin{array}{c}13.46 \\
(11.76-15.02)\end{array}$ & $\begin{array}{c}20.63 \\
(18.84-15.01)\end{array}$ & $\begin{array}{c}24.80 \\
(22.79-27.03)\end{array}$ & $\begin{array}{c}29.80 \\
(27.33-32.85)\end{array}$ & $\begin{array}{c}45.77 \\
(40.62-52.96)\end{array}$ & $\begin{array}{c}134.11 \\
(105.35-185.27)\end{array}$ & 5.49 & 0.24 \\
\hline
\end{tabular}

1SD = Standard deviation, $\mathrm{LD}=$ Lethal dose $\left(\mu \mathrm{L}^{-1} / 50 \mathrm{~g}\right.$ cowpea $), \mathrm{FI} 95 \%=$ Fiducial intervals at $95 \%$ of probability, $\chi 2=$ Chisquare, $\mathrm{P}=$ Probability.

Instantaneous rate of increase $\left(r_{i}\right)$ and mass losses. The instantaneous rate of increase $\left(r_{i}\right)$ was used to estimate the eugenol fumigant effects on the biological development of $C$. maculatus. The instantaneous rate of increase of $C$. maculatus was significantly reduced in a dose-dependent manner in the presence of eugenol $(\mathrm{F}=27.35 ; d f=5 ; \mathrm{P}<0.001)$. Although the $r_{i}$ values decreased linearly with increasing doses of eugenol, only the $\mathrm{LD}_{99}$ was able to cause C. maculatus extinction resulting in the final number of live insects almost equal to zero (Figure 1A). In a similar trend, the mass losses of the cowpea beans exposed to eugenol were significantly $(\mathrm{F}=145.73 ; d f=5$; $\mathrm{P}<0.001)$ smaller than those of the untreated control (Figure 1B). The losses caused by the development of $C$. maculatus were up to $78 \%$ less in bean masses treated with doses higher than the $\mathrm{LD}_{60}$ compared to the losses found for the untreated beans.
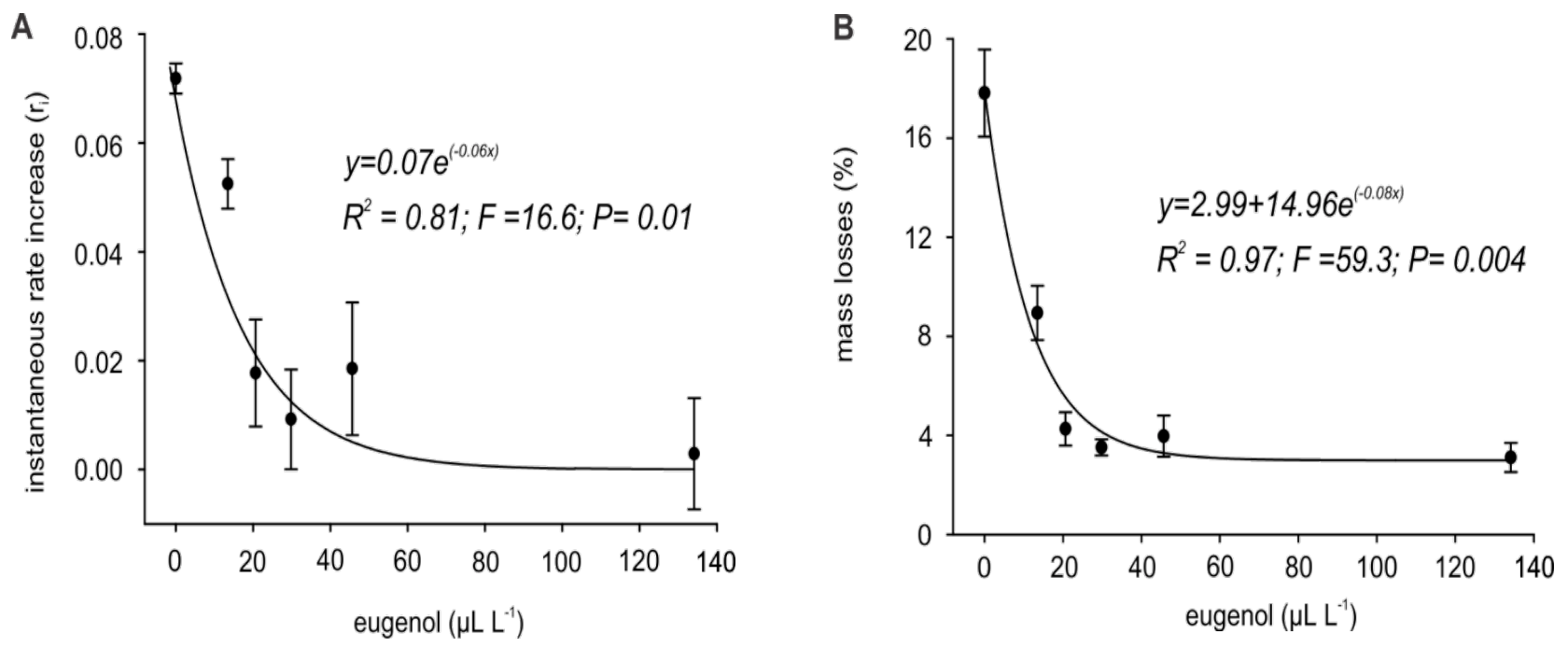

The symbols represent the mean of five replicates and the vertical bars represent the SD.

Figure 1. Instantaneous rate of increase $r_{i}(\mathrm{~A})$ of $C$. maculatus and mass losses of cowpea beans (B) exposed to different fumigant doses of eugenol $\left(\mu \mathrm{L}^{-1} / 50 \mathrm{~g}\right.$ cowpea beans). 
Emergence bioassay. The daily emergence of adult weevils was significantly different when the grain masses were infested by unexposed or eugenol exposed insects (Figure 2). Both the number of progeny individuals (Figure 2A) and the time to maximum emergence (Figure 2B) were negatively affected by exposure to

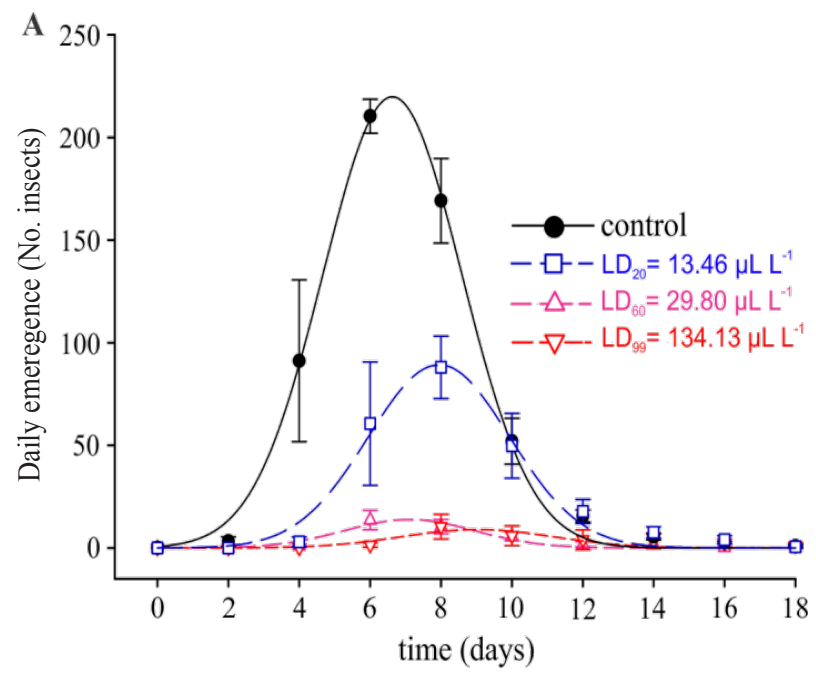

eugenol. Indeed, even the smallest tested dose $\mathrm{LD}_{20}$ caused a smaller peak of emergence (more than $50 \%$ smaller) and a delay in the time of maximum emergence of 1- 2 days compared to the control while higher doses almost abolished the progeny emergence.

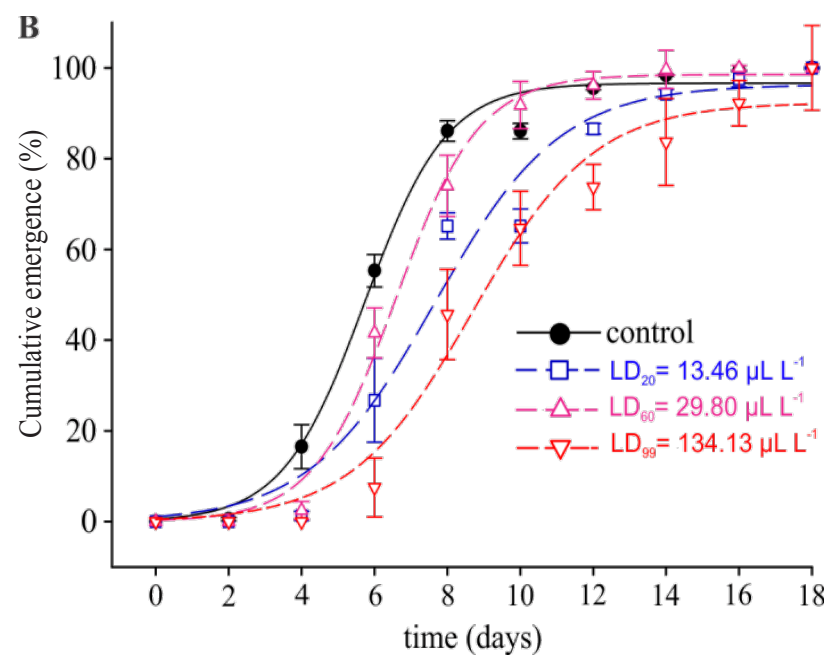

The symbols represent the mean of five replicates and the vertical bars represent the SD.

Figure. 2. Daily emergence (A) and cumulative emergence (B) of progeny of $C$. maculatus exposed to increased fumigant concentration of eugenol $\left(\mu \mathrm{L}^{-1}\right)$.

Repellence bioassay. Repellence to C. maculatus was dependent of the fumigated dose of eugenol (Figure3), while the $\mathrm{LD}_{50}\left(24.80 \mu \mathrm{L} \mathrm{L}^{-1}\right)$ of eugenol presented attracting effects to $C$. maculatus $(t=-12.05, d f=4, \quad P<0.001)$, the beans treated with $\mathrm{LD}_{99}\left(134.13 \mu \mathrm{L} \mathrm{L}^{-1}\right)$ were significatively repellent to $C$. maculatus $(t=3.26$, $d f=4, P=0.031$ ).

As part of the continuous and active quest for cheaper, safe and eco-friendly alternatives to chemical insecticides, several plant oils and their major constituents have been screened as potential tools preventing post-harvest losses due to insects. Here, we evaluated the fumigant application of eugenol at lethal and sublethal doses and its effects on biological traits of C. maculatus, a key pest of stored beans. Our results showed, good fumigant insecticidal activity of eugenol acompained with a decrease of the growth rate of $C$. maculatus and a reduction in bean mass losses. Additionally, significant inhibition of the offspring emergence was achieved after the exposure of parental adults to lethal and sublethal doses of eugenol. Interestingly, the behavior of the adult weevil in front of eugenol exposed beans balanced between attraction at low dose and repellency at higher ones. 
The bars represent the mean of five replicates and the vertical bars represent the SD. *Significant difference between the number of individuals in the treated and untreated by test $t(P<0.05)$.

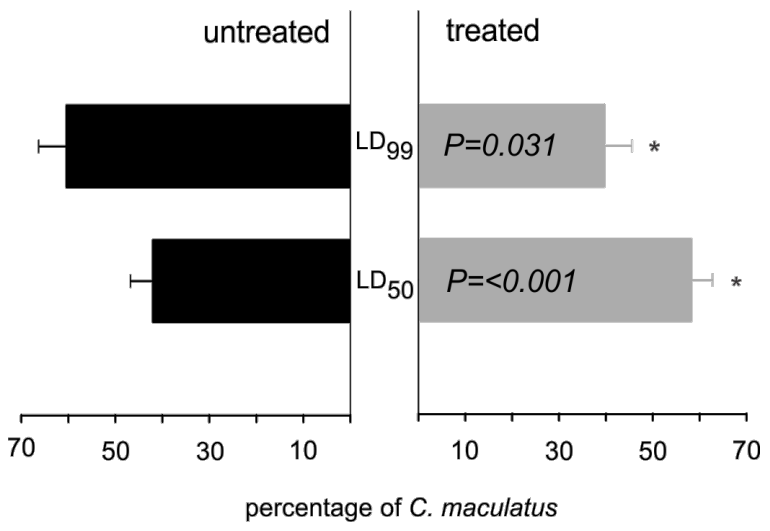

Figure 3. Repellences (\%) to C. maculatus after $24 \mathrm{~h}$ of exposure to cowpea beans untreated and treated with $\mathrm{LD}_{50}\left(24.80 \mu \mathrm{L} \mathrm{L}^{-1}\right)$ and $\mathrm{LD}_{99}(134.13$ $\mu \mathrm{L} \mathrm{L}^{-1}$ ) of eugenol in fumigant application.

Although a majority of the studies on the toxicity of essential oils; against C. maculatus and other stored products pests; have mostly tested crude essential oils; different works with individual synthetic compounds suggest that the insecticidal activities of these essential oils are due principally to their primary constituents such as eugenol. Indeed, various studies have reported that this terpenoid has acaricidal (Ribeiro et al., 2016), insecticidal (Larson et al., 2017; Saad et al., 2018), termiticidal (Xie et al., 2015) and fungicidal (Koeduka et al., 2014) activities.

Eugenol belongs to monoterpenes, a large group of volatile and lipophilic compounds which are able to rapidly penetrate inside insects and interfere with their physiological functions (Saad et al., 2018). The mode of action of monoterpenes in insects is still not well understood although it has been studied by various authors (Soujanya et al. (2016). In contact application, eugenol and other monoterpenes are fast-acting insecticides that are effective on a wide variety of insects and mites (Dayan et al., 2009), working by disrupting the octopaminergic (or via its precursor tyramine) transmission on the insect nervous system (Enan, 2001; Enan, 2005). As a fumigant compound, the respiratory system should be the main entrance route of eugenol and other monoterpenes into the insect body, making the respiratory system the potential major target site for eugenol. In a recent study, it has been shown that eugenol have a strong inhibition of acetylcholinesterase (AChE) and adenosine triphosphatases (ATPases) activities in Sitophilus oryzae, but also that the fumigant toxicities of the monoterpenes such as eugenol are higher than their contact and/ or oral toxicities (Athanassiou et al., 2014; Saad et al., 2018). Furthermore, eugenol-rich essential oils (e.g., clove essential oil) that exhibited insecticide activity similar to the activity recorded for deltamethrin (Viteri Jumbo et al., 2018) can be easily biodegraded by microorganisms (Mishra, S. \& Sachan, S. 2013; Kadacol, J. \& Kamanavalli, C. 2010).

In addition to the good toxicity of eugenol, fumigant application of this compound also resulted in a significant inhibition of the offspring emergence even at sublethal doses. Negative effects on biological traits including rates of growth, grain consumption and progeny emergence of $C$. maculatus can be the results of direct mortality of adults, repellency, oviposition or progeny deterrence and growth inhibition (Athanassiou etal., 2014; Germinara etal., 2015). Similar effects have been reported in Sitophilus zeamais when exposed to other essential oils or their monoterpenes constituents (Nattudurai et al., 2017; Silva et al., 2017). In fact, monoterpenes such as eugenol are volatile and can penetrate between the grains, enhancing the exposure of different stages of the pest to the treatment. Such easy circulation between the grains is an advantage to these compounds that makes them 
useful as fumigants (Athanassiou et al., 2014). Furthermore, the inhibition of emergence of new insects was positively correlated with lower grain consumption, probably due to a lower feeding activity of $C$. maculatus larvae or due to the progeny deterrence.

In this study, the repellence activity of eugenol was dependent of the fumigation dose. Indeed, being able either to repel or attract insects (Atkinson, 2018; Baker and Grant, 2018), the eugenol exposed beans were attractive to $C$. maculatus insects at a dose of $\operatorname{LD}_{50}(24.80 \mu \mathrm{L}$ $\mathrm{L}^{-1}$ ) while eugenol presented repellent action at high fumigant dose $\left(\mathrm{LD}_{99}=134.13 \mu \mathrm{L} \mathrm{L}^{-1}\right)$ in accordance with previous studies (Kafle and Shih, 2013; Reis et al., 2016; Viteri Jumbo et al., 2014; Zeringóta et al., 2013). Such attractant activity of eugenol has been suggested for use in formulations for trapping beetles attacking horticultural crops, particularly those in the scarab family such as the Japanese beetle, Popillia japonica Newman and the white-spotted flower chafer, Protaetia brevitarsis (Baker and Grant, 2018).

\section{CONCLUSIONS}

Eugenol exhibited good insecticidal activity and increments in the fumigation dosages proportionately decreased the growth rate of C. maculatus. Additionally, eugenol delayed the biological development and significantly reduced the bean weight losses caused by C. maculatus and showed repellent activity at high doses against the cowpea bean weevils whereas its activity in low doses may serve as an attractant in lures for other pests and could be subject of study object. Thus, our results revealed that eugenol can be part of a comprehensive integrated C. maculatus management program in storage facilities (especially for small farmers), which favors environment friendly pest control strategies.

\section{ACKNOWLEDGMENTS}

We thank to Departamento de Engenharia Agrícola, Universidade Federal de Viçosa, Viçosa MG,Brazil.Thisworkwas supported bygrantsfrom the Secretaria Nacional de Educación Superior Ciencia y Tecnología of Ecuador (SENESCYT), Grants from the CAPES Foundation (Finance code 001), the National Council of Scientific and Technological Development (CNPq), the Minas Gerais State Foundation for Research Aid (FAPEMIG).

Conflict of interest: The authors declare that there is no conflict of interest.

\section{BIBLIOGRAPHIC REFERENCES}

Athanassiou, C.G., Rani, P.U. \& Kavallieratos, N.G. (2014). The use of plant extracts for stored product protection, In: Singh, D. (Ed.). Advances in plant biopesticides. pp. 131-147. New Delhi: Springer.

Atkinson, R.G. (2018). Phenylpropenes: Occurrence, Distribution, and Biosynthesis in Fruit. Journal of Agricultural and Food Chemistry. 66(10): 22592272. doi: 10.1021/acs.jafc.6b04696

Baker, B.P. \& Grant, J.A. (2018). Eugenol Profile. Recovered from https://ecommons.cornell.edu/ bitstream/handle/1813/56125/eugenol-MRPNYSIPM.pdf?sequence=1\&isAllowed=y.

Chang, S. T. \& Cheng, S. S. (2002). Antitermitic activity of leaf essential oils and components from Cinnamomum osmophleum. Journal of Agricultural and Food Chemistry. 50(6): 13891392. doi: 10.1021/jf010944n

Dayan, F. E., Cantrell, C. L., \& Duke, S. 0. (2009). Natural products in crop protection. Bioorganic \& medicinal chemistry, 17(12), 4022-4034. doi: 10.1016/j.bmc.2009.01.046. 
El-Maati, M.F.A., Mahgoub, S.A., Labib, S.M., Al-Gaby, A.M., Ramadan, M.F. (2016). Phenolic extracts of clove (Syzygium aromaticum) with novel antioxidant and antibacterial activities. European Journal of Integrative Medicine. 8(4): 494-504. doi: 10.1016/j.eujim.2016.02.006

Enan, E. (2001). Insecticidal activity of essential oils: octopaminergic sites of action. Comparative Biochemistry and Physiology Part C: Toxicology \& Pharmacology. 130(3): 325-337. doi: 10.1016/ S1532-0456(01)00255-1

Enan, E.E. (2005). Molecular response of Drosophila melanogaster tyramine receptor cascade to plant essential oils. Insect Biochemistry and Molecular Biology. 35(4): 309-321. doi: 10.1016/j. ibmb.2004.12.007

Freitas, R.C.P., Faroni, L.R.D.A., Haddi, K., Viteri Jumbo, L.0., Oliveira, E.E. (2016). Allyl isothiocyanate actions on populations of Sitophilus zeamais resistant to phosphine: Toxicity, emergence inhibition and repellency. Journal of Stored Products Research 69: 257-264. doi: 10.1016/j. jspr.2016.09.006

Gbaye, O.A., Oyeniyi, E.A., Ojo, O.B. (2016). Resistance of Callosobruchus maculatus (Fabricius) (Coleoptera: Bruchidae) populations in Nigeria to dichlorvos. Jordan J. Biol. Sci. 9(1): 41-46. doi: 10.12816/0027007

Germinara, G.S., De Cristofaro, A., Rotundo, G. (2015). Repellents effectively disrupt the olfactory orientation of Sitophilus granarius to wheat kernels. Journal of Pest Science. 88(4): 675-684. doi: 10.1007/s10340-015-0674-y

Haddi, K., Faroni, L.R., Oliveira, E.E. (2017). Cinnamon Oil, in: Leo M.L. Nollet, H.S.R. (Ed.) Green Pesticides Handbook, Essential Oils for Pest Control pp. 117-150. 1st Edition. Boca Raton: CRC Press. 523p.

Haddi, K., Jumbo, L.V., Costa, M., Santos, M., Faroni, L., Serrão, J., Oliveira, E. (2018). Changes in the insecticide susceptibility and physiological trade-offs associated with a host change in the bean weevil Acanthoscelides obtectus. Journal of Pest Science. 91(1): 459-468. doi: 10.1007/ s10340-017-0860-1
Isman, M.B., Grieneisen, M.L. (2014). Botanical insecticide research: many publications, limited useful data. Trends in Plant Science. 19(3): 140145. doi: 10.1016/j.tplants.2013.11.005

Iturralde-García, R.D., Borboa-Flores, J., CincoMoroyoqui, F.J., Riudavets, J., Del Toro-Sánchez, C.L., Rueda-Puente, E.0., Martínez-Cruz, 0., Wong-Corral, F.J. (2016). Effect of controlled atmospheres on the insect Callosobruchus maculatus Fab. in stored chickpea. Journal of Stored Products Research 69: 78-85. doi: 10.1016/j.jspr.2016.06.004

Kadakol, J. C. \& Kamanavalli, C. M. (2010). Biodegradation of eugenol by Bacillus cereus strain PN24. Journal of Chemistry. 7(S1): S474-S480.

Kafle, L. \& Shih, C.J. (2013). Toxicity and repellency of compounds from clove (Syzygium aromaticum) to red imported fire ants Solenopsis invicta (Hymenoptera: Formicidae). Journal of Economic Entomology. 106(1): 131-135. doi: 10.1603/ EC12230

Kaliramesh, S., Chelladurai, V., Jayas, D., Alagusundaram, K., White, N. \& Fields, P. (2013). Detection of infestation by Callosobruchus maculatus in mung bean using near-infrared hyperspectral imaging. Journal of Stored Products Research 52: 107-111. doi: 10.1016/j.jspr.2012.12.005

Kang, J.K., Pittendrigh, B.R. \& Onstad, D.W. (2013). Insect resistance management for stored product pests: a case study of cowpea weevil (Coleoptera: Bruchidae). Journal of Economic Entomology. 106(6): 2473-2490. doi: 10.1603/ EC13340

Koeduka, T., Sugimoto, K., Watanabe, B., Someya, N., Kawanishi, D., Gotoh, T., Ozawa, R., Takabayashi, J., Matsui, K. \& Hiratake, J. (2014). Bioactivity of natural 0-prenylated phenylpropenes from Illicium anisatum leaves and their derivatives against spider mites and fungal pathogens. Plant Biology. 16(2): 451-456. doi: 10.1111/ plb.12054

Larson, N.R., Carlier, P.R., Gross, A.D., Islam, R.M., Ma, M., Sun, B., Totrov, M.M., Yadav, R. \& Bloomquist, J.R. (2017). Toxicology of potassium channel-directed compounds in mosquitoes. NeuroToxicology. 60: 214-223. doi: 10.1016/j. neuro.2016.05.021. 
Lopes, L.M., Sousa, A.H., Santos, V.B., Silva, G.N. \& Abreu, A.0. (2018). Development rates of Callosobruchus maculatus (Coleoptera: Chrysomelidae) in landrace cowpea varieties occurring in southwestern Amazonia. Journal of Stored Products Research, 76: 111-115. doi: 10.1016/j. jspr.2018.01.008

Massango, H., Faroni, L., Haddi, K., Heleno, F., LO, V.J. \& Oliveira, E. (2017). Toxicity and metabolic mechanisms underlying the insecticidal activity of parsley essential oil on bean weevil, Callosobruchus maculatus. Journal of Pest Science. 90(2): 723-733. doi: 10.1007/s10340016-0826-8

Melo, B.A.d., Molina-Rugama, A.J., Haddi, K., Leite, D.T. \& Oliveira, E.E.d. (2015). Repellency and bioactivity of Caatinga biome plant powders against Callosobruchus maculatus (Coleoptera: Chrysomelidae: Bruchinae). Florida Entomologist. 98(2): 417-423. doi: 10.1653/024.098.0204

Mishra, S., Sachan, A., \& Sachan, S. G. (2013). Production of natural value-added compounds: an insight into the eugenol biotransformation pathway. Journal of industrial microbiology \& biotechnology. 40(6): 545-550. doi: 10.1007/s10295013-1255-9

Mkenda, P.A. \& Ndakidemi, P.A. (2014). Pesticidal efficacy of four botanical pesticides on survival, oviposition and progeny development of bruchid, Callosobruchus maculatus in stored cowpea, Vigna unguiculata. International Journal of Plant \& Soil Science. 3(12): 1504-1523.

Nattudurai, G., Baskar, K., Paulraj, M.G., Islam, V.I.H., Ignacimuthu, S. \& Duraipandiyan, V. (2017). Toxic effect of Atalantia monophylla essential oil on Callosobruchus maculatus and Sitophilus oryzae. Environmental Science and Pollution Research. 24(2): 1619-1629. doi: 10.1007/ s11356-016-7857-9

Pavela, R. \& Benelli, G. (2016). Essential oils as ecofriendly biopesticides? Challenges and constraints. Trends in Plant Science. 21(12): 1000-1007. doi: 10.1016/j.tplants.2016.10.005

Polatoğlu, K. \& Karakoç, Ö.C. (2016). Chapter 5 Biologically Active Essential Oils against Stored Product Pests A2. In: Preedy, V. R., Essential Oils in Food Preservation, Flavor and Safety. pp. 3959. San Diego: Academic Press.

Purohit, P., Jayas, D., Yadav, B., Chelladurai, V., Fields, P. \& White, N. (2013). Microwaves to control Callosobruchus maculatus in stored mung bean (Vigna radiata). Journal of Stored Products Research. 53: 19-22. doi: 10.1016/j. jspr.2013.01.002.

Reis, L.S., Mantello, G.A., Macedo, M.J., Gelfuso, A.E., da Silva, P.C., Fachin, L.A., Cardoso, M.A. \& Beleboni, O.R. (2016). Typical Monoterpenes as Insecticides and Repellents against Stored Grain Pests. Molecules. 21(3): 258. doi: 10.3390/ molecules21030258

Ribeiro, N., Camara, C. \& Ramos, C. (2016). Toxicity of essential oils of Piper marginatum Jacq. against Tetranychus urticae Koch and Neoseiulus californicus (McGregor). Chilean Journal of Agricultural Research. 76(1): 71-76. doi: 10.4067/S0718-58392016000100010

Saad, M.M., Abou-Taleb, H.K. \& Abdelgaleil, S.A. (2018). Insecticidal activities of monoterpenes and phenylpropenes against Sitophilus oryzae and their inhibitory effects on acetylcholinesterase and adenosine triphosphatases. Applied Entomology and Zoology, 53(2): 173-181 . doi: 10.1007/s13355-017-0532-x

Silva, S., Haddi, K., Viteri Jumbo, L. \& Oliveira, E. (2017). Progeny of the maize weevil, Sitophilus zeamais, is affected by parental exposure to clove and cinnamon essential oils. Entomologia Experimentalis et Applicata. 163(2): 220-228. doi: 10.1111/eea.12559

Soujanya, P.L., Sekhar, J.C., Kumar, P., Sunil, N., Prasad, C.V. \& Mallavadhani, U.V. (2016). Potentiality of botanical agents for the management of post harvest insects of maize: a review. Journal of Food Science and Technology. 53(5): 2169-2184. doi: 10.1007/s13197-015-2161-0

Viteri Jumbo, L.O., Faroni, L.R., Oliveira, E.E., Pimentel, M.A. \& Silva, G.N. (2014). Potential use of clove and cinnamon essential oils to control the bean weevil, Acanthoscelides obtectus Say, in small storage units. Industrial Crops and Products 56, 27-34. doi: 10.1016/j.indcrop.2014.02.038

Viteri Jumbo, L.O., Haddi, K., Faroni, L. R. D., Heleno, F. F., Pinto, F. G., \& Oliveira, E. E. (2018). Toxicity to, oviposition and population growth impairments of Callosobruchus maculatus exposed to clove and cinnamon essential oils. PloS one. 13(11): e0207618. doi: 10.1371/journal.pone.0207618 
Walthall, W.K. \& Stark, J.D. (1997). Comparison of two population-level ecotoxicological endpoints: The intrinsic (rm) and instantaneous (ri) rates of increase. Environmental Toxicology and Chemistry. 16(5): 1068-1073. doi: 10.1002/ etc. 5620160529 .

Xie, Y., Yang, Z., Cao, D., Rong, F., Ding, H., Zhang, D. (2015). Antitermitic and antifungal activities of eugenol and its congeners from the flower buds of Syzgium aromaticum (clove). Industrial Crops and Products 77, 780-786. doi: 10.1016/j. indcrop.2015.09.044

Zeringóta, V., Senra, T.O.S., Calmon, F., Maturano, R., Faza, A.P., Catunda-Junior, F.E.A., Monteiro, C.M.O., de Carvalho, M.G. \& Daemon, E. (2013). Repellent activity of eugenol on larvae of Rhipicephalus microplus and Dermacentor nitens (Acari: Ixodidae). Parasitology Research. 112(7): 2675-2679. doi: 10.1007/s00436-013-3434-z. 